\title{
Experimental Investigation and Fuzzy Logic Modelling of Performance Hydroxy Dry Cell with Different Plate Combination
}

\author{
Abdullah Işııtaş ${ }^{1}$, Kevser Dincer $^{2}$, Ali Verim² ${ }^{2}$, Osman Türkmen², Sadık Ata ${ }^{* 3}$ \\ Accepted 3rd September 2016
}

\begin{abstract}
In this study, hydroxy (HHO) dry cell with different plate combination performances in terms of current and temperature were experimentally investigated and modeled with Rule-Based Mamdani-Type Fuzzy (RBMTF) modeling technique. Input parameters plate number and time; output parameters current, temperature were described by RBMTF if-the rules. The dimensions of the plates were $9 \times 9 \mathrm{~cm}^{2}, 10 \times 10 \mathrm{~cm}^{2}$ and $11 \times 11 \mathrm{~cm}^{2}$. Current and temperature were measured for the different plate combination. Tap water was used in the experiments and the system was set to 5 minutes. For each combination, new cells were prepared. Experimental data which obtained for current and temperature according to combination and time were used in the training step. Numerical parameters of input and output variables were fuzzificated as linguistic variables: very very low (L1), very low (L2), low (L3), negative medium (L4), medium (L5), positive medium (L6), high (L7), very high (L8) and very very high (L9) linguistic classes. With the linguistic variables used, rules were obtained for this system. The comparison between experimental data and RBMTF is done by using statistical methods like the coefficient of multiple determinations $\left(\mathrm{R}^{2}\right)$. The actual values and RBMTF results indicated that RBMTF can be successfully used in HHO dry cell.
\end{abstract}

Keywords: HHO Dry Cell, Plate Combination, Rule-based Mamdani-type fuzzy modeling.

\section{Introduction}

Hydrocarbon fuel is one of the sources of energy used for electrical power generation, heating and transportation in the world. But they have negative side effects like polluting emissions, large scale oil spill, etc. Due to its widespread dependence and difficulties in getting other alternatives the use of hydrocarbon fuel could not be eliminated. To mitigate the above problems and to reduce the use of hydrocarbon fuel, hydrogen gas can be supplemented. Hydrogen gas to air intake of a combustion process will improve flame speed, lean burn ability and flame quenching distance. But scarcity and production cost makes it more difficult to implement. Hydrogen rich gas produced from electrolysis of water called the Brown's Gas or Oxyhydrogen (HHO) could solve the potential difficulties [1]. In 1918 Charles Frazer, a North American inventor, patented the first water electrolysis machine act as a hydrogen booster for internal combustion engines. Yull Brown, a Bulgarian born Australian inventor patented and attempted to popularize Browns Gas as a cutting gas and fuel additive during the 1970's and 80 's [2]. HHO is an enriched mixture of hydrogen and oxygen bonded together molecularly and magnetically. HHO Gas is produced in a common-ducted electrolyser \& then sent to the intake manifold to introduce into combustion chamber of the engine. HHO gases will combust in the combustion chamber when brought to its auto-ignition or self-ignition temperature [3]. This Energy's performance must be increased which is predicted to be more important in the future. One of the methods to determine the

\footnotetext{
${ }^{1}$ Sinop University, Machine and Metal Techn.. Department, Sinop

${ }^{2}$ Selcuk University, Department of Mechanical Eng., Konya

${ }^{3}$ KTO Karatay University, Department of Mechanical Eng., Konya

* Corresponding Author: Email: sadik.ata@karatay.edu.tr

Note: This paper has been presented at the $3^{\text {rd }}$ International Conference on Advanced Technology \& Sciences (ICAT'16) held in Konya (Turkey), September 01-03, 2016.
}

effects of the parameters on performance is fuzzy logic method. In the existing literature, there have been many investigations on application of fuzzy logic. Some of briefly mentioned below. Işıktaş et al. [4] studied about fuzzy logic modelling of performance HHO dry cell with different type membership functions. They noted that RBMTF which has a triangular membership function has a more better performance than other membership functions for determine performance of HHO dry cell. Ata and Dincer [5-9] studied about rule-based Mamdanitype fuzzy (RBMTF) modelling of performance proton exchange membrane fuel cell with carbon nanotube. They noted that RBMTF can be successfully used for the specification PEM performances with coating carbon nanotube. Özek et al. [10] studied modelling of air conditioning system by fuzzy logic approach, because one of the main problems in control systems is the difficulty to form the mathematical model associated with the control mechanism. They realized that the fuzzy logic without using mathematical model of control system can create control mechanism only with the help of linguistic variables. Kim et al. [11] examined an electrical modelling of the fuel cell generation system. They used fuzzy logic controller to overcome inherent disadvantages such as uncontrollable large overshoot and large current ripple. They noted that fuzzy controller is very effective in output control and desired operating point operation, which in turn offers high system stability and performance. Tong et al. [12] studied about $1 \mathrm{~kW}$ PEM fuel cell unit and developed the models of stack voltage, cathode flow, anode flow. They proposed that the power demand of the external load can be provided by the fuel cell stack under the control of a real-time simplified variable universe fuzzy controller. Tiryaki et al. [13] studied about dishwasher which is frequently used in daily life is modelled and simulated by using fuzzy logic. They concluded that if an appropriate hardware support and appropriate sensors are provided for the dishwasher, with the aim of the fuzzy logic model the washing process may be done without human 
intervention according to the inputs such as quantity of the dishes, type of the dishes by the machine.

In this experimental study, three different plate combinations compared in terms of HHO dry cell performance. Also in this study, Rule-based Mamdani-type fuzzy modeling used to evaluate performance of $\mathrm{HHO}$ dry cells with different plate combination. Performance parameters are plate numbers, time, current and temperature. Study includes fuzzification of input variables, representation of fuzzy set with 9 linguistic variables, formation of rule basis and a comparison between output values obtained by experiments and by calculation based on generated rules and RBMTF technique

\section{Materials and Methods}

Fuzzy logic is a superset of Boolean-conventional logic that has been expanded to handle the concept of partial truth and truth values between "completely true" and "completely false". Fuzzy theory should be seen as a methodology to generalize any specific theory from crisp to continuous. Fuzzy modelling opens the possibility for straightforward translation of statements in natural language-verbal formulation of the observed problem-into a fuzzy system. Its functioning is based on mathematical tools [14].Fuzzy inference system consists of a fuzzification interface, a rule base, a database, a decision-making unit, and finally a defuzzification interface. The function of each block is as follows. A rule base containing a number of fuzzy IF-THEN rules, a database which defines the membership functions of the fuzzy sets used in the fuzzy rules, a decision-making unit which performs the inference operations on the rules, a fuzzification interface which transforms the crisp inputs into degrees of match with linguistic values and a defuzzification interface which transforms the fuzzy results of the inference into a crisp output. Mamdani's method is the most commonly used in fuzzy inference system, due to its simple structure of 'min-max' operations. Mamdani's method can be used is widely used in fields which require specialized knowledge and is a fuzzy logic method that can be applied to any solution of all kind of problem [15].

The knowledge base of RBMTF is a collection of fuzzy IF-THEN rules. The term fuzzy logic denotes a modelling approach, where functional dependencies between the input and output variables are described by means of a set of IF-THEN rules following the reasoning wih the operators AND, OR and NOT in general linguistic usage. RBMTF is a type of fuzzy relational model where each rule is represented by an IF-THEN relationship. [16]. The aim of this experimental study is to compare different plate combination for HHO dry cell performance and to model fuzzy logic method. With the aid of experimental data, HHO dry cell performances at different plate combination in terms of current and temperature were modeled with Rule-Based Mamdani-Type Fuzzy (RBMTF) modeling technique. RBMTF was designed using MATLAB fuzzy logic toolbox. In the developed RBMTF system, output parameter current and temperature was determined using inlet parameters plate numbers and time. Hereafter the rules, which are used to detect the behavior of the fuzzy logic controller and the relationship between system's input and output, are determined. As a result of these rules, every value obtained from the experimental study is also determined by fuzzy logic too.

\section{Results and Discussion}

In this experimental study which is used to detect HHO dry cell performance; the effect of the plate number and time on current and temperature is investigated. Experimental system was set to 5 minutes. Current and temperature values are obtained on every plate from 60th second to 300th second by 60 second intermittently in the experimental study. The aim of this study with the aid of experimental data, HHO dry cell performances in terms of current and temperature were modeled with fuzzy logic modeling technique. In the developed RBMTF system, output parameters $\mathrm{A}$ and $\mathrm{T}$ were determined using inlet parameters plate number and $\mathrm{t}$.

Figs. 1-2 shows respectively comparison of experimental data for $9 \times 9 \mathrm{~cm}^{2}, 10 \times 10 \mathrm{~cm}^{2}$ and $11 \times 11 \mathrm{~cm}^{2}$ plate dimensions for current and temperature.

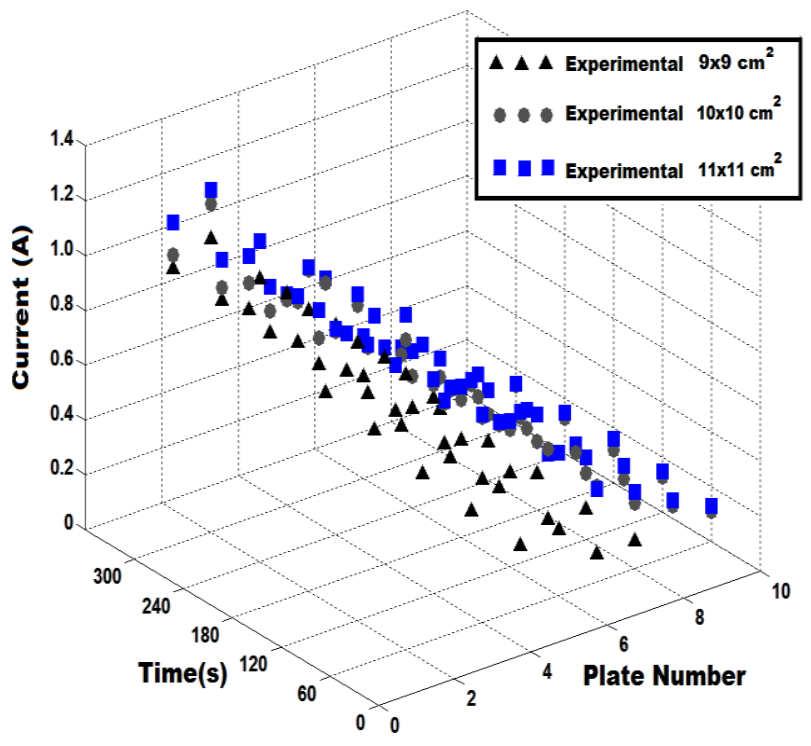

Figure 1. Comparison of experimental data for the variation of time with plate number of current values for different plate dimension

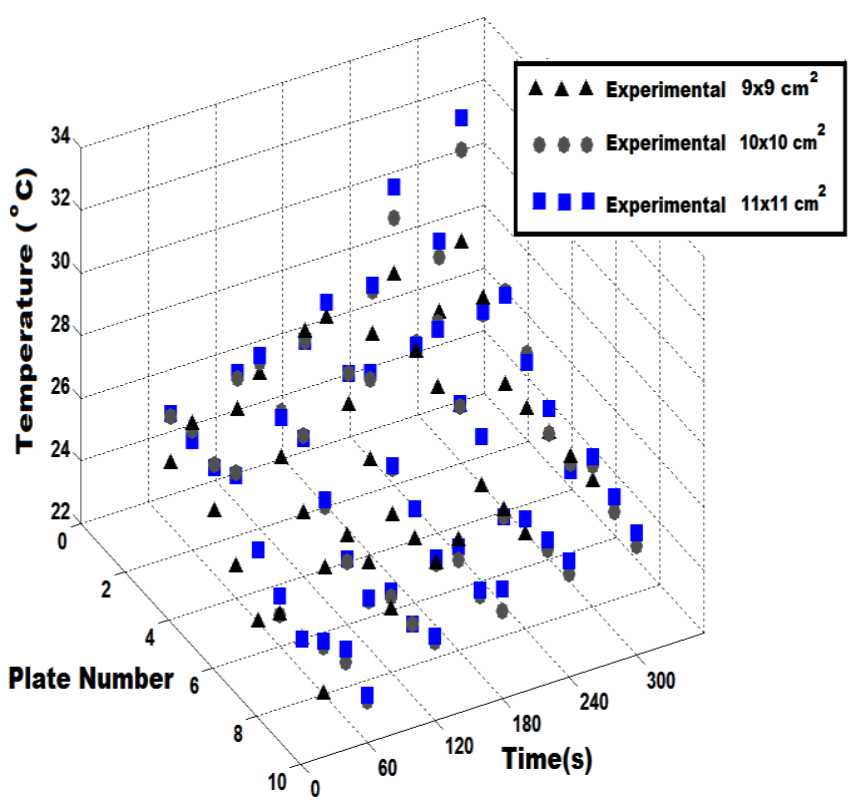

Figure 2. Comparison of experimental data for the variation of time with plate number of temperature values for different plate dimension

These figures present that;

- $11 \times 11 \mathrm{~cm}^{2}$ and $10 \times 10 \mathrm{~cm}^{2}$ has more better performance than $9 \times 9 \mathrm{~cm}^{2}$. 
- In the case of each plate temperature increases by the course of time and the current value decreases by the increasing plate number.

- According to the experiments, high temperature has been found $29^{\circ} \mathrm{C}, 32^{\circ} \mathrm{C}$ and $33{ }^{\circ} \mathrm{C}$ and current density has been found $0.02 \mathrm{~A} / \mathrm{cm}^{2}, 0.023 \mathrm{~A} / \mathrm{cm}^{2}$ and 0.024 $\mathrm{A} / \mathrm{cm}^{2}$ for $9 \times 9 \mathrm{~cm}^{2}, 10 \times 10 \mathrm{~cm}^{2}$ and $11 \times 11 \mathrm{~cm}^{2}$ respectively (Figs 1-2).

Figs. 3-8 shows respectively comparison of experimental data with RBMTF for the variation of time with combination of current and temperature values for $9 \times 9 \mathrm{~cm}^{2}, 10 \times 10 \mathrm{~cm}^{2}$ and $11 \times 11 \mathrm{~cm}^{2}$ plate dimensions (plate number $=1-10 ; \mathrm{t}=60-300 \mathrm{~s}$ ). From a comparison of the experimental results with the results of the fuzzy logic study, one can see that the results are quite compatible (Figs. 3-8).

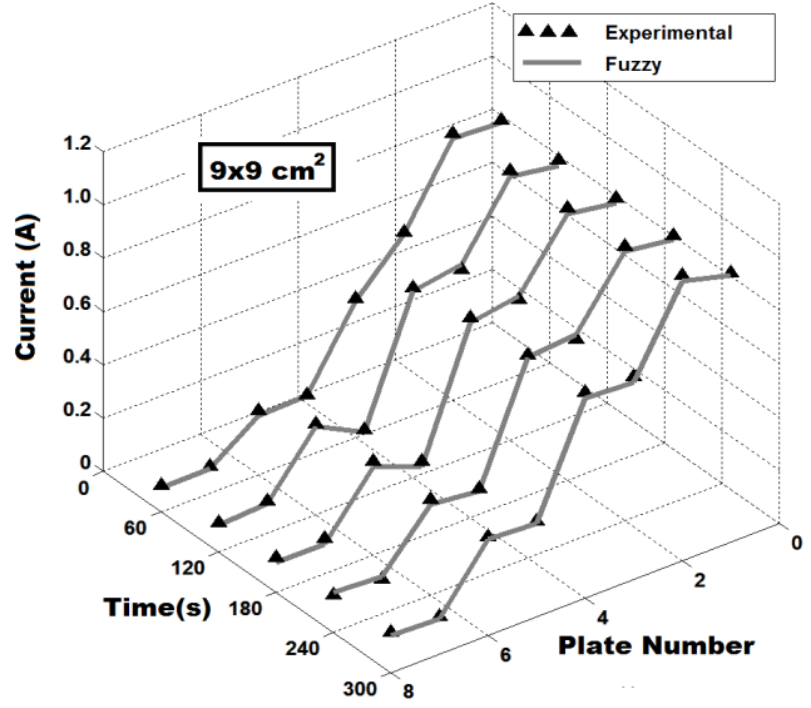

Figure 3. Comparison of experimental data with RBMTF for the variation of time with plate number of current values for $9 \mathrm{x} 9 \mathrm{~cm}^{2}$ plate dimension

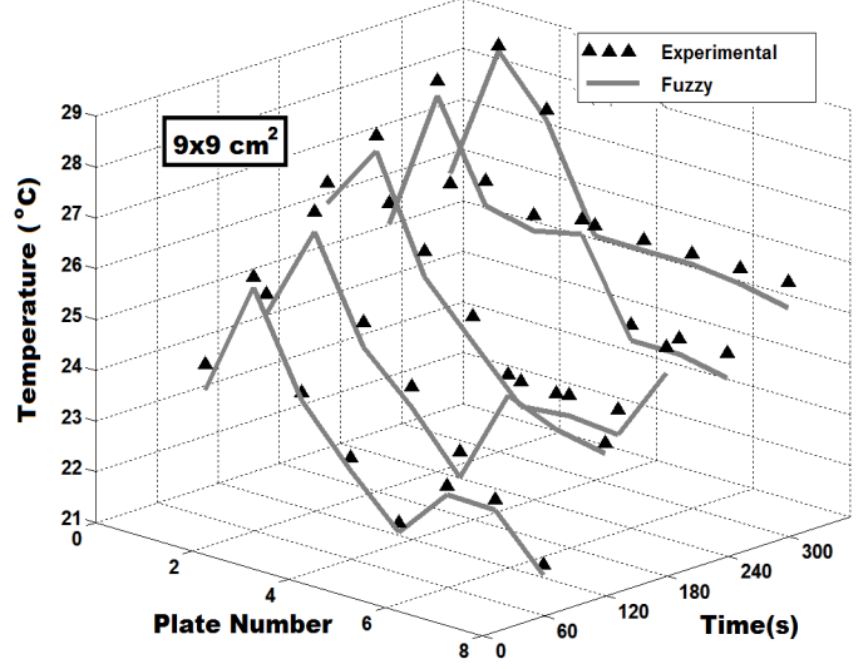

Figure 4. Comparison of experimental data with RBMTF for the variation of time with plate number of temperature values. for $9 \times 9 \mathrm{~cm}^{2}$ plate dimension

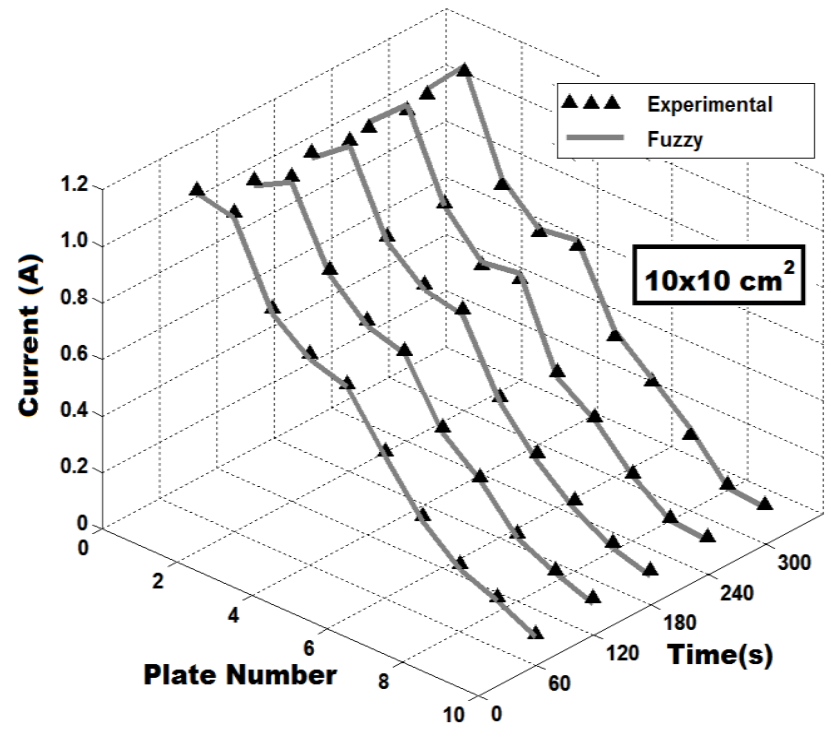

Figure 5. Comparison of experimental data with RBMTF for the variation of time with plate number of current values for $10 \times 10 \mathrm{~cm}^{2}$ plate dimension

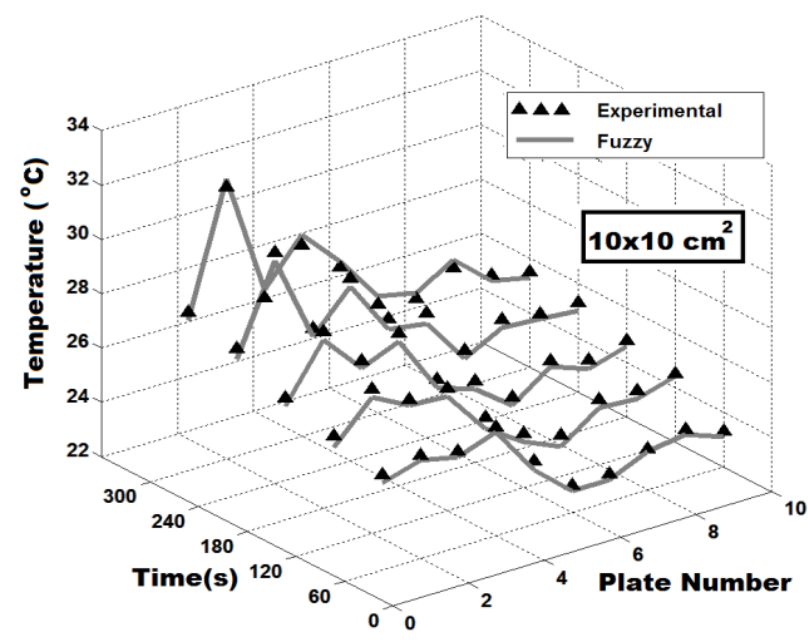

Figure 6. Comparison of experimental data with RBMTF for the variation of time with plate number of current values for $10 \times 10 \mathrm{~cm}^{2}$ plate dimension

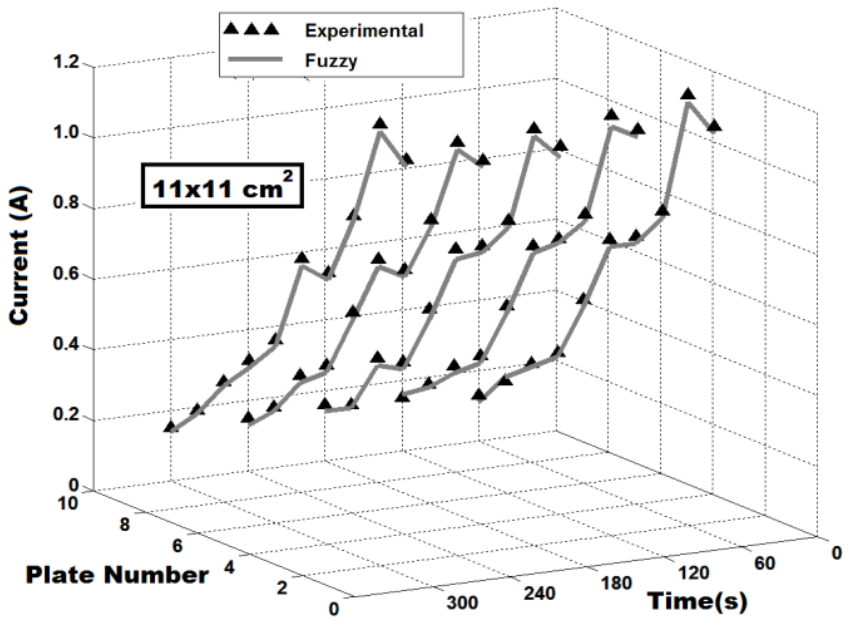

Figure 7. Comparison of experimental data with RBMTF for the variation of time with plate number of current values for $11 \times 11 \mathrm{~cm}^{2}$ plate dimension 


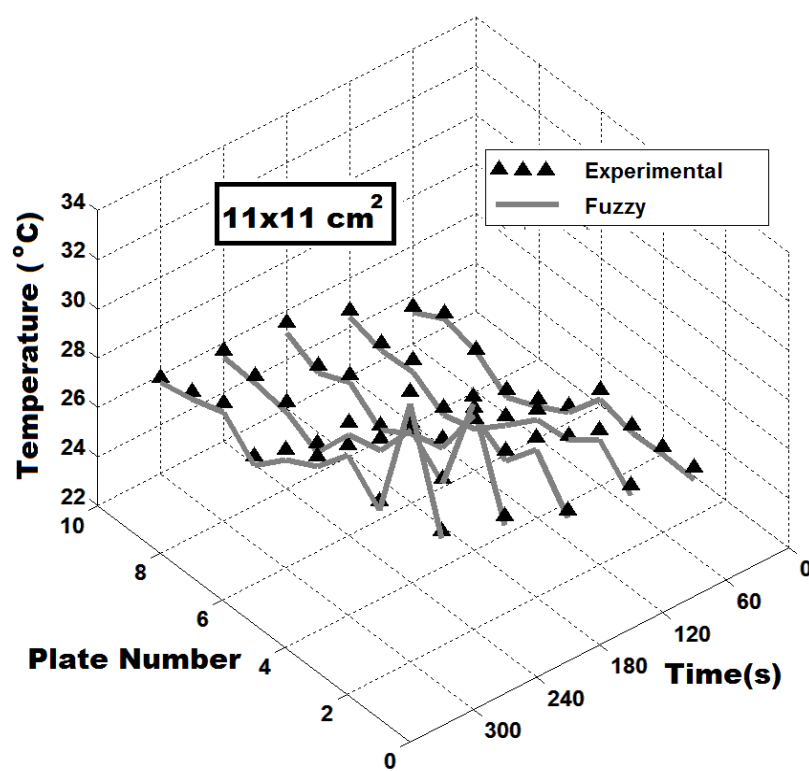

Figure 8. Comparison of experimental data with RBMTF for the variation of time with plate number of current values for $11 \times 11 \mathrm{~cm}^{2}$ plate dimension

Figs. 3-8 present that;

- For 9x9 $\mathrm{cm}^{2}$, the maximum current value is $1.07 \mathrm{~A}$ at $9-7$ combination and $300 \mathrm{~s}$. For $10 \times 10 \mathrm{~cm}^{2}$, the maximum current value is $1.2 \mathrm{~A}$ at $11-9$ combination and $300 \mathrm{~s}$. For $11 \times 11 \mathrm{~cm}^{2}$, the maximum current value is $1.25 \mathrm{~A}$ at $11-9$ combination and $300 \mathrm{~s}$.

- For 9x9 $\mathrm{cm}^{2}$, the minimum current value is $0.1 \mathrm{~A}$ at $9-1$ combination and $60 \mathrm{~s}$. For $10 \times 10 \mathrm{~cm}^{2}$, the minimum current value is $0.11 \mathrm{~A}$ at $11-1$ combination and $60 \mathrm{~s}$. For $11 \times 11 \mathrm{~cm}^{2}$ the minimum current value is $0.13 \mathrm{~A}$ at $11-1$ combination and $60 \mathrm{~s}$.

- $\quad$ For $9 \times 9 \mathrm{~cm}^{2}$, the maximum temperature value is $29^{\circ} \mathrm{C}$ at $9-7$ combination and $300 \mathrm{~s}$. For $10 \times 10 \mathrm{~cm}^{2}$, the maximum temperature value is $32{ }^{\circ} \mathrm{C}$ at $11-9$ combination and $300 \mathrm{~s}$. For $11 \times 11 \mathrm{~cm}^{2}$, the maximum temperature value is $33{ }^{\circ} \mathrm{C}$ at $11-9$ combination and $300 \mathrm{~s}$

- For $9 \times 9 \mathrm{~cm}^{2}$, the minimum temperature value is $22^{\circ} \mathrm{C}$ at $9-1$ combination and $60 \mathrm{~s}$. For $10 \times 10 \mathrm{~cm}^{2}$, the maximum temperature value is $23{ }^{\circ} \mathrm{C}$ at $11-4$ combination and $300 \mathrm{~s}$. For $11 \times 11 \mathrm{~cm}^{2}$, the maximum temperature value is $23{ }^{\circ} \mathrm{C}$ at $11-4$ combination and $300 \mathrm{~s}$

The comparison between experimental data and fuzzy logic is done using statistical methods such as the coefficient of multiple determination $\left(\mathrm{R}^{2}\right)$ are defined as follows, where $\mathrm{n}$ is the number of data patterns, $\mathrm{y}_{\mathrm{p}}$ ${ }_{i}$ ndicates the predicted, $\mathrm{t}_{\mathrm{m}, \mathrm{m}}$ is the actual value of one data point $\mathrm{m}$, and ${ }_{\mathrm{m}, \mathrm{n}}$ is the mean value of all actual data points [17]. When Table 1 is observed it is found that actual values and the values from fuzzy technique are very close to each other.

$$
R^{2}=1-\frac{\sum_{m=1}^{n}\left(t_{m, m}-y_{p, m}\right)^{2}}{\sum_{m=1}^{n}\left(t_{m, m}-\bar{t}_{m, m}\right)^{2}}
$$

Table 1. Comparison of different plate dimensions for current and temperature

\begin{tabular}{|c|c|c|}
\hline \multirow{2}{*}{$\begin{array}{c}\text { HHO Dry Cell } \\
\text { Plate Dimensions }\end{array}$} & \multicolumn{2}{|c|}{$\mathbf{R}^{2}$} \\
\cline { 2 - 3 } & Current (A) & Temperature $\left({ }^{\circ} \mathrm{C}\right)$ \\
\hline $9 \times 9 \mathrm{~cm}^{2}$ & $98.49 \%$ & $97.2 \%$ \\
\hline $10 \times 10 \mathrm{~cm}^{2}$ & $98.6 \%$ & $97.8 \%$ \\
\hline $11 \times 11 \mathrm{~cm}^{2}$ & $98.23 \%$ & $97.5 \%$ \\
\hline
\end{tabular}

\section{Conclusions}

In this study, HHO dry cell performances at different plate combinations in terms of current and temperature were experimentally investigated. For HHO dry cell, $11 \times 11 \mathrm{~cm}^{2}$ and $10 \times 10 \mathrm{~cm}^{2}$ has better performance than $9 \times 9 \mathrm{~cm}^{2}$. With the aid of experimental data, $\mathrm{HHO}$ dry cell performances at different plate combination in terms of current and temperature were modeled fuzzy logic technique. In the developed RBMTF system, output parameters A, T was determined using inlet parameters plate number and t. Every value obtained from the experimental study is also determined by fuzzy logic too. The comparison between fuzzy logic and experimental data is done using statistical methods. $\mathrm{R}^{2}$ is calculated for the current value $98.49 \%$ at $9 \times 9$ $\mathrm{cm}^{2}, 98.6 \%$ at $10 \times 10 \mathrm{~cm}^{2}$ and $98.23 \%$ at $11 \times 11 \mathrm{~cm}^{2} . \mathrm{R}^{2}$ is calculated for the temperature value $97.2 \%$ at $9 \times 9 \mathrm{~cm}^{2}, 97.8 \%$ at $10 \times 10 \mathrm{~cm}^{2}$ and $97.5 \%$ at $11 \times 11 \mathrm{~cm}^{2}$. The actual values and RBMTF results indicated that RBMTF can be successfully used for the specification $\mathrm{HHO}$ dry cell performances at different plate combination.

\section{Acknowledgment}

Financial support of experimental study from the research fund of the Selcuk University under Grant No. BAP 16201048 is gratefully acknowledged. In addition, this study constitutes part of the ongoing Master thesis of Abdullah Işıktaş.

\section{References}

[1] E. Leelakrishnan, N. Lokesh, H. Suriyan, "Performance and emission characteristics of Brown's gas enriched air in spark ignition engine," International Journal of Innovative Research in Science, Engineering and Technology, vol.2, pp. 393-404, 2013.

[2] R. Cameron, "Effects of on-board HHO and water injection in a diesel generator," Bachelor of Engineering Research Project, University of Southern Queensland Faculty of Engineering and Surveying, 2012.

[3] S. Yadav Milind, S.M. Sawant, "Investigations on oxyhydrogen gas and producer gas as alterntive fuels on the performance of twin cylinder diesel engine," International Journal of Mechanical Engineering and Technology (IJMET), vol.2, pp.85-93, 2011.

[4] A. Işıktaş, K. Dincer, S. Ata,"Comparison Between the Effects of Different Types of Membership Functions on Fuzzy Logic for Hydroxy Dry Cell Performance," 16th International Multidisciplinary Scientific GeoConference SGEM 2016, Bulgaria, 2016.

[5] S. Ata, K. Dincer, "Rule-based Mamdani-type fuzzy modeling of performance proton exchange membrane fuel cell with carbon nanotube," 15th International Multidisciplinary Scientific GeoConference SGEM 2015, Bulgaria, 487-494, 2015. [6] S. Ata, K. Dincer, "Anot Tarafi Karbon Nanotüp İle Kaplanmış PEM Yakıt Hücresi Performansının Bulanık Mantık Yöntemiyle Modellenmesi," Ulusal Hidrojen Teknolojileri Kongresi UHTEK-2015, İstanbul, 2015. 
[7] S. Ata, "PEM Yakı Hücresinin Membran Performansının Deneysel Olarak İncelenmesi ve Enerji Ayrışımı Olayının Bulanık Mantık Yöntemi ile Modellenmesi," Yüksek Lisans Tezi, Selçuk Üniversitesi Fen Bilimleri Enstitüsü, Konya, 2015.

[8] S. Ata, K. Dincer, "Bulanık Mantık Yaklaşımıyla Yakıt Hücresi Performansının Belirlenmesi," V. Ulusal Güneş ve Hidrojen Enerjisi Kongresi, Eskişehir, 2016.

[9] S. Ata, K. Dincer, "Improving the Performance of Proton Exchange Membrane Fuel Cell Using Fuzzy Logic," 18th International Conference on Energy and Sustainable Development, Paris, 16-17 May 2016.

[10] A. Özek, M. Sinecen, "Klima sistem kontrolünün bulanık mantık ile modellemesi," Pamukkale Üniversitesi Mühendislik Bilimleri Dergisi, Cilt 10, Sayı 3, 2004.

[11] Y. Kim, S. Kim, "An Electrical Modelling and Fuzzy Logic Control of a Fuel Cell Generation System," IEEE Transactions on Energy Conversion, vol. 14, no. 2, pp. 239-244, 1999.

[12] S.W. Tong, D.W. Qian, J.J. Fang, H.X. Li, “Integrated Modelling and Variable Universe Fuzzy Control of a HydrogenAir Fuel Cell System," Int. J. Electrochem. Sci., vol.8, pp. 36363652, 2013.

[13] A.E. Tiryaki, R. Kazan, "Bulaşık makinesinin bulanık mantık ile modellenmesi," Mühendis ve Makine, Cilt 48, Sayı 565, ss. 3-8, 2007.

[14] A. Ates, T. Akbiyik, K. Dincer, "The fuzzy logic modelling of diesel engine emissions using fuel mixed with different ratios of hydrogen," International Journal of Automotive Engineering and Technologies, vol. 2, issue 4, pp. 111 - 117, 2013.

[15] M. Bölgen, "Fuzzy logic and data mining technıques in evaluating of credit risks of companies," Master Thesis, Graduate School of Natural and Applied Sciences of Dokuz Eylül University, Turkey, 2010.

[16] M. Tosun, K. Dincer, S. Baskaya, "Rule based Mamdani-type fuzzy modelling of thermal performance of wall types most used in residential buildings in Turkey," 10th International Multidisciplinary Scientific Geoconference SGEM 2010, Albena, Bulgaria, 2010.

[17] G. Önal, K. Dincer, S. Yayla, Y. Yılmaz, A.S Ersoyoğlu, "Pt/C Coating for Proton Exchange Membrane Fuel Cell (PEMFC) and Rule-Based Mamdani-Type Fuzzy Modeling of PEMFC Performance," International Journal of Mining, Metallurgy \& Mechanical Engineering, vol.3, no.3, pp.122-128, 2015. 